\title{
Writing on Islamic Apologetics in an Unwritten Tongue. An Unusual Sample of Transitional Prose from the Island of Soqotra*
}

\author{
Escribir apologética islámica en una lengua \\ sin escritura: una muestra extraordinaria \\ de prosa transicional de la isla de Socotra
}

\section{LEONID KogaN}

National Research University-Higher School of Economics

Staraya Basmannaya, 21. Moscow, Russia

Ikogan@hse.ru

Orcid ID 0000-0002-1195-6636
RECIBIDO: 22 DE ABRIL DE 2020 ACEPTADO: 9 DE SEPTIEMBRE DE 2020
Abstract: Soqotri is a Modern South Arabian language spoken by 100 ooo inhabitants of the Island of Soqotra. The island is famous for its narrative art, first revealed to the Western world by the Austrian South Arabian Expedition around 1900. Until recently, Soqotri functioned as an unwritten language, and Soqotra's traditional lore has mainly been transmitted orally. From 2014 on, an Arabic-based writing system for Soqotri has been implemented by a Russian-Yemeni research team. Originally intended as a means of preservation of the traditional oral lore, the writing system proves to be capable of meeting other intellectual demands - notably, to create original, non-traditional compositions. Apo- logetic and propagandistic works pertaining to the Muslim faith are among the first genres of the nascent Soqotri prose. The article analyzes one such composition in an attempt to trace the thorny path from orality to literacy on Soqotri soil: the adaptation of traditional narrative techniques; the difficult balance between purism and innovation; and interaction with Arabic. It shows that the concept of transitional text, mostly applied to poetry in modern literary research, can also be used about prose, including religiously motivated writing.

Keywords: Soqotra. Yemen. Orality. Literacy. Islam. Contact Phenomena.

\footnotetext{
* My work on the article has been carried out in the framework of the project 20-02-002 supported by National Research University HSE.
} 
Resumen: El socotrí es una lengua actual del sur de Arabia hablada por 100 ooo habitantes de la isla de Socotra. La isla es famosa por su arte narrativo, revelado al mundo occidental por la expedición austríaca al sur de Arabia alrededor de 1900. Hasta tiempos recientes, el socotrí ha funcionado como una lengua no escrita, y la cultura tradicional de Socotra se ha transmitido principalmente de forma oral. Desde 2014, un sistema de escritura basado en el árabe se ha puesto en marcha gracias a un equipo de investigación ruso-yemení. Concebido originalmente como un medio para la conservación de la cultura oral tradicional, el sistema de escritura resulta capaz de afrontar otras exigencias intelectuales; particularmente, de realizar composiciones originales, no tradicionales.
Obras apologéticas y propagandísticas de la fe musulmana constituyen los primeros géneros de la naciente prosa socotrí. El artículo analiza una de estas composiciones con el objetivo de trazar el espinoso camino de la oralidad a la escritura en el suelo de Socotra: la adaptación de técnicas narrativas tradicionales; el difícil equilibrio entre purismo e innovación; y la interacción con el árabe. Se muestra así que el concepto de texto transicional, aplicado especialmente a la poesía en la investigación literaria actual, también puede usarse en relación con la prosa, incluyendo escritos de motivación religiosa.

Palabras clave: Socotra. Yemen. Oralidad. Escritura. Islam. Fenómenos de contacto.

\section{INTRODUCTION}

A year ago, we published, in collaboration with my language consultant and friend Isa Gum'an al-Da'rhi, ${ }^{1}$ what can be considered the first authored text in the Modern South Arabian language Soqotri, spoken by ca. 100000 inhabitants of the island of Soqotra (Gulf of Aden, Yemen). ${ }^{2}$

For the modern Western world the Soqotri language was discovered by the British navy official James R. Wellstedt, who visited the island in JanuaryMarch of 1835. However, it took about 70 years for Soqotri to become an integral part of Semitic linguistics and philology. Its re-discovery at the turn of the $20^{\text {th }}$ century is firmly associated with the name of the prominent Austrian scholar David Heinrich Müller. ${ }^{3}$ From the mid-1970s, linguistic and folklore

1. ad-Da'rhi/Kogan/Cherkashin (Soqotri text in Semitological transcription and the Arabic-based Soqotri writing; English translation; philological and linguistic annotations). For the sake of brevity, the text will not be reproduced here in its entirety; for the details, the original edition has to be consulted.

2. An up-to-date survey on Soqotri grammar and ethonolinguistics can be found in Kogan/Bulakh 2019.

3. A smaller part of Müller's corpus, published in 1902, was collected from several individuals in the course of his trip to the island in 1899. The most valuable part of the 1902 volume is a small collection of very archaic poetic fragments with parallel translations in German and semicolloquial Arabic. For many of the verses, Müller was also able to obtain brief lexical annota- 
research on Soqotra has been resumed by Vitaly Naumkin. Since 2010, systematic fieldwork on a variety of grammatical and folklore-related topics has been carried out on the island by a team of Russian scholars headed by Naumkin, closely collaborating with four language consultants from the Da'arho tribe (central-eastern part of inner Soqotra). The chief output of this large-scale project is the Corpus of Soqotri Oral Literature (CSOL), whose two published volumes (CSOL I, 2014 and CSOL II, 2018) will prominently feature below in this study. ${ }^{4}$

In contrast to virtually all previously published Soqotri texts, the sample dealt with in the present article possesses many essential features of an authored composition: it does not reproduce any traditional plot or motif, but has been purposely created from scratch by a known individual compiler, who carried out his work with the express aim of publication. Last but not least, the text was not narrated, but carefully written down by the author himself by means of the previously elaborated Arabic-based Soqotri script. ${ }^{5}$

The present study analyzes this composition as an unusual type of transitional text - a religiously motivated prose treatise in a nascent written language with a rich and varied oral tradition. In the wake of Parry and Lord, students of 'transitional texts' typically have oral poetry as the starting point of their research. This trend continues even today - in recent years research related to Oral-Formulaic theory was mostly focused on poetry (Ford 2018; Gintsburg 2014, 2017, 2019; Murray 2019). There is, however, no a priori

tions. Remarkably, the poems were recorded not only in transcription, but also in the Arabic script. The most important part of Müller's Soqotri legacy was published in 1905. It comprises the texts recorded during a six-month working season in Vienna in 1902 from one single informant, ৎĀlī ৎĀmer an-Nubhān, born in the village of Kam, not too far from Soqotra's capital Hadibo. The narrative part of the 1905 volume comprises ca. 150 pages of Soqotri texts translated into German. Among the texts, there is a good selection of Old Testament translations (from Arabic) and a few other texts with an Arabic background. The remaining texts are pure specimens of the autochthonous oral lore. The poetic part of the book comprises no less than ca. 750 smaller and larger compositions. In 1918, M. Bittner published the first six chapters of the Gospel of Mark, translated into Soqotri by Müller with the help of his informant. As will be shown below, the religious-oriented compositions from the 'Vienna corpus' are of prime importance for the topic of the present study.

4. For a detailed presentation of this project see Naumkin et al. 2014: 1-42.

5. More details on the Soqotri writing, whose original insight and subsequent development are largely due to Isa Gum'an's natural philological talents and exemplary devotion, can be found in Naumkin et al. 2014: 25-29. Born in 1970 as a member of the Da'rho tribe, Isa is a teacher of Islamic sciences in a primary school in Hadibo, Soqotra's capital town. During the last years of the Socialist regime in the Southern Yemen (PDRY), he was able to graduate from a pedagogical college in Aden, where he acquired a good command of spoken and written Arabic. He has a good knowledge of the Quran and other basic texts of the Muslim creed. 
reason not to apply this useful concept to prose, be it narrative, ${ }^{6}$ memorial, ${ }^{7}$ para-scientific ${ }^{8}$ or other. ${ }^{9}$ It is my expectation that this contribution will invite specialists to have a closer look at the research potential of such 'transitional prose' and its implications for a variety of neighbouring disciplines, such as sociolinguistics, anthropology, religious studies, etc.

For obvious reasons, linguistic and literary interaction between Soqotri and Arabic will be within the focus of our inquiry. Throughout the text, the author's outspoken puristic ambition, aiming at establishing Soqotri as a fullyfledged written medium capable of rendering comparatively sophisticated religious themes, ${ }^{10}$ is countered by the massive pressure of Arabic as the language of education, administration, external communication and media. As such, this tension is not new to us, as it is found in many, maybe most, other texts recorded and analyzed by our research team. But here it inevitably reaches its

6. With regard to its background, the Soqotri narrative folklore published in CSOL belongs to two different categories. Some samples directly go back to Naumkin's early tape recordings of 1970-1980s, their narrators are usually not available (mostly passed away) and the deciphering was done with the assistance of our language consultants. Other texts were recorded directly from our Da'rho informants of younger generations, who are able to read, write and converse in literary and dialectal Arabic. Even for the first category of texts, a considerable deal of written adaptation inevitably takes place, whereas in the second case the 'transitional' status of the written and published output is beyond doubt.

7. Memorial narratives - that is, personal records of events from the more or less remote past are not very numerous on the pages of CSOL I-II. Good examples are the stories about encounters with jinni women (CSOL I No. 18, CSOL II Nos. 16-18), a man's account of his troubles in times of drought (CSOL I No. 29) or the description of the court procedures by the former sultan of Mahra and Soqotra (CSOL II No. 26).

8. CSOL (particularly Volume Two) features many texts which would traditionally be attributed as 'ethnographic': accounts of local household activities (CSOL II No. 2, milk production: No. 3, meat preserves; Nos. 9-11, date palm and dates; No. 27, building techniques), descriptions of flora and fauna (CSOL i No. 30: 'The Pernicious Botfly'), etc. Soqotrans prove to be extremely fond of such compositions, which they produce with great care and a truly scientific sense of responsibility. Structural and stylistic features of this corpus, undoubtedly another prime example of 'transitional prose', await a comprehensive descriptive and comparative investigation.

9. To be sure, the possibility of studying such texts has not totally escaped the attention of literary theoreticians: consider, for example, E. Jahner's study of the writings of the $19^{\text {th }}$ century American Indian political leader and thinker George Sword. As aptly described by Jahner, while some of his texts are 'direct transcriptions of speech', other 'show significant evidence of the reflective reconsiderations and aesthetic structuring when writing provokes awareness of text as artifact' (150). Undoubtedly, much still remains to be done in this field both in terms of methodology and accumulating practical experience. This, however, does not mean that nothing is being done. This volume, for instance, offers another curious example of transitional prose in the language of haketia (Moscoso).

10. Thus restoring its reputation, marred in the eyes of many by its intrinsic connection with the 'archaic', 'backward' traditional Soqotra, supposedly incompatible with the Arab and Islamic 'modernity'. This and other related topics are treated in depth in the recent monograph-size study by S. D. Elie. 
peak because of the religious subject of the text: in his composition, Isa Gum'an boldly enters the domain where the use of any language other than Arabic is considered unthinkable by the majority of today's Soqotrans (and, undoubtedly, many other Muslim minorities living in an Arabic-speaking milieu throughout the Middle East and North Africa). ${ }^{11}$

The presence of Arabic loanwords is a superficial, yet fairly reliable means of assessing the Arabizing trend in the text, with a special attention to Arabic religious terminology directly borrowed from the mainstream Islamic discourse. At the opposite extreme, a deeper inquiry into the native, Soqotribased religious lexicon will be helpful to assess the philological creativity of the author and the extent of his puristic ambitions.

In addition, I will briefly touch upon a few other aspects of Isa's perception of the Soqotri literary heritage and its amalgamation with 'modern' culture - notably, the author's use of the traditional riddle as the main constitutive element of his composition. Finally, the author's unconscious attempts at translating certain segments of the Quranic text into Soqotri will be singled out and analyzed. In the concluding part of the article, another hitherto unpublished composition from the pen of the same author will be offered to the readers' judgement, in an attempt to show that Isa's Soqotri-based Islamic appeal is not limited to one single text sample.

\section{STRUCTURE AND CONTENTS OF THE TEXT}

The tripartite arrangement of the text closely follows one of the most widespread types of the Soqotri fairy tale: a narrative framework (introduction + conclusion) encasing a stylistically different kernel where the main ideological and artistic truth of the whole composition is encapsulated.

In the Introduction (Segments 1-18 of the published text), an unnamed Muslim shows up in a religious meeting of a certain community of 'nonbelievers' (in all probability, Christians), whose leader threatens him with death unless he immediately leaves the place. The Muslim refuses and proposes a kind of trial - to answer a set of questions of a religious nature. If he answers wrongly, the community is free to kill him, but if his answers are correct, they will convert to Islam. Here the main part of the text begins (Segments 19-

11. This is the main reason why other members of the Da'arho tribe were so strongly opposed to the inclusion of this text in the forthcoming third volume of CSOL and urged Isa to publish it separately and on his own responsibility. 
146), which closely resembles a question-and-answer catechism encompassing the major plots of Abrahamic (but, de facto, mostly Quranic ${ }^{12}$ ) Sacred History. In terms of composition, this 'Islamic Catechism' occupies the slot which in a traditional Soqotri fairy tale would be reserved for a poem. ${ }^{13}$ In the closing part of the text (Segments 147-62), the Muslim's answers prove to be compellingly true, and the audience, headed by its leader, converts into Islam and transforms its congregation hall (presumably, a church) into a mosque.

Isa's 'Islamic Catechism', while certainly a novel text type with no direct forerunner in the Soqotri oral literature, did not emerge ex nibilo, but takes its inspiration from the traditional riddle - a deeply rooted and once very popular genre of Soqotri folklore. ${ }^{14}$ Even a quick comparison between the two collections mentioned in the preceding footnote makes it clear that the art of the traditional riddle has substantially deteriorated over the past hundred years: if confronted with Müller's collection, the riddles one could glean today from the members of our community are less numerous, they structures are more stereotyped and the subjects covered, as well as the images involved, considerably more limited in scope. ${ }^{15}$ It is, therefore, not surprising that most of the 23 'riddles' of Isa's 'catechism' are rather primitive in form and contents: their functionality as a literary device has clearly overridden their artistic creativity. About half of them (riddles 1-9 in the published version) are unsophisticated numerical questions of the type 'What is one and has no two?' (answer: God).

12. It is not without interest that, in his treatise, Isa does not restrict himself to the Quran alone, incorporating into his narrative a few pertinent extra-Quranic sources, first and foremost, the Qișas al-'Anbiya' (exact references to both types of sources can be found throughout adDa'rhi/Kogan/Cherkashin). The aim at combining different sources into one narrative framework - and the ability to do that - is another prominent feature of an authored work which the present text shares.

13. As my experience with the Soqotri narrative folklore teaches, there are many reasons to believe that, diachronically, the poetic segment is the primary nucleus of the composition, for which the narrative framework was later created (sometimes not very thoroughly) as a kind of etiological justification - an interesting phenomenon certainly worth of further in-depth investigation in a broader comparative perspective. It is not unlikely that a similar avenue of the author's thought underlies the present composition, the 'question-and-answer' kernel having emerged before the 'conversion narrative'.

14. The first collection of Soqotri riddles was published by D. H. Müller (1905: 359-64), the second, by our research team (Naumkin et al. 2018: 178-90 = CSOL II No. 12). There are all reasons to believe that the very idea of creating the 'Islamic Catechism' was triggered by Isa's involvement in the edition of CSOL II. Needless to say, 'Islamic Catechisms' have and do exist(ed) elsewhere in the Arab and Muslim world (as the one translated in Jeffery), but they do not seem to be focused on Sacred History as the present text is. In any case, it is hard to say now whether any similar Arabic text was used by Isa before or during his work on the present specimen.

15. Thus, riddles related to sexual issues (quite numerous in the Vienna Corpus) are - or at least seem to be - completely banned from the oral culture of today's Soqotrans. 
The remaining samples can be classified (following Chyet's typology) as oppositional antithetical contradictive (e.g. 10, 16, 20) ${ }^{16}$ and non-oppositional metaphorical (e.g. 15, 22). ${ }^{17}$

\section{ISLAMIC TERMINOLOGY IN THE TEXT: ARABIC VS. SOQOTRI}

\section{Arabic loanwords outside the religious sphere}

Before we start to deal with the 'native vs. borrowed' dichotomy in the religious terminology of our text, a more general assessment of the Arabic lexical influence in this composition is necessary.

A certain quantity of Arabic loanwords is present in nearly every Soqotri text known to date. ${ }^{18}$ Their number, fairly low in early texts, inevitably increases in modern recordings, but even now the Soqotri vocabulary is more conservative than its continental sister tongues Jibbali and especially Mehri. Due to the manifestly purist intentions of our linguistic consultants, the presence of recent, non-assimilated Arabisms in the texts of our corpus is generally rather low, and the specimen under scrutiny is no exception. What follows is a brief typological survey of Arabisms in Isa's treatise.

\section{- Compelling borrowings}

Truly compelling Arabisms - that is, those which could hardly be replaced by autochthonous equivalents - are very few in the present text, which is easily

16. (10) What are ten, but many? - Good deeds (multiplied by God as a reward to those who perform them); (16) What is this thing that breathes, but has no spirit? - Morning (with reference to Quran 81: 18); (20) Who are the non-believers that entered Paradise? - Joseph's brothers.

17. (15) What is the grave that moves together with its occupant? - Jonah's whale; (22) What is the tree with twelve branches, and on each branch thirty leaves, and each leaf has five dates, and from these three are in the shade and two in the sun? - The year, the months, the days, the five prayers, three of them in darkness and two in daylight.

18. In strictly linguistic terms, a distinction has to be made between fully integrated loans and occasional, more superficial Arabic lexical insertions. The former can be described as a restricted group of early borrowings (many of them verbs), whereas the latter can be borrowed more or less ad libitum due to the widespread Arabic-Soqotri bilingualism and code-switching. As we will see below, many 'native' religious terms actually turn out to be deeply integrated Arabisms, in all probability going back to the times of the islanders' very first acquaintance with Islam. Borrowings belonging to the latter type, too, are not totally alien even to the earliest published records of Soqotri, but, needless to say, rapidly grow in number nowadays. Regrettably, no comprehensive study of the Arabic lexical influence on Soqotri (or any other MSA language) exists at present. 
explainable by its contents, far removed from material and conceptual 'modernity'. Two curious exceptions belong to the realm of fauna: dib 'wolf' and $\hat{z}$ eféde ' 'frogs'. Neither wolves nor frogs are present on the island, ${ }^{19}$ but their mention is the text could not be avoided because of their involvement in the Exodus and Joseph narratives respectively. ${ }^{20}$ To this group may also belong besćtin 'palm-groves', well attested already in the Vienna corpus (LS 90) and having no native equivalent because palm cultivation must be a comparatively recent introduction on the island. See also kamiș 'shirt' in the Joseph story ${ }^{21}$ (if one assumes that the Arabic word designates - or is thought to designate - a type of garment originally missing from Soqotra) and harásis 'soldiers, guards', describing the Pharaoh's army pursuing the Israelites. ${ }^{22}$

\section{- Non-compelling borrowings}

The bulk of the Arabisms in the text pertains to 'semi-cultural' concepts for which the compiler could theoretically provide native equivalents. These are, however, either non-existent (or at least not known to us from the extant sources) ${ }^{23}$ or have been considered too archaic and cumbersome in comparison to the current Arabic borrowings (no Soqotri-based neologisms have been created to fill the pertinent slots). ${ }^{24}$ Here belong mes'úl' 'officer, person

19. Soqotra is well-known for a very reduced repertoire of wild mammals, especially predators (Wranik 77-92). The absence of frogs is less well known, but no less remarkable: 'So far no traces of amphibians have been found on the [Soqotra] archipelago, despite there being adequate water conditions and the presence of a number of species in the adjacent areas of Africa and Arabia ... There is no conclusive explanation for this' (Wranik 151).

20. The former had been used as early as in Müller 1905: 97/2-5 (LS 120).

21. Already in the Vienna corpus (LS 377). In Müller's translation of the first chapter of the Biblical Joseph story (1907: 45-51), it alternates with another Arabism dešdése (LS 137).

22. The word is not found in the Vienna corpus, but is often used in the fairy tales of CSOL when a sultan's armed retinue is described.

23. Something not totally unexpected from a language of a - till recently - heavily isolated, premodern community, which displays an incredible wealth of terminology related to natural phenomena or traditional economic practices, but is poor in words for abstract concepts. A telling witness to this effect is the adjectival concept 'new', for which no inherited Soqotri exponent was recorded by Müller. The issue is, moreover, not merely lexical, but also cognitive: the very concept of 'newness' or 'being new' is thoroughly missing from Müller's very extensive text collections. What we find in a couple of lone exceptions (one of them in a Biblical translation!) is the Arabic loanword gedid (Müller 1902: 64/3) - just as in the modern language.

24. While generally rare, such neologisms are not totally unknown from the texts processed by our team. A prime example is mešómtil' 'translator, interpreter, tourist guide', an 'old participle' from šémtal 'to talk' (CSOL I 614). 
in charge' designating the head of the unbelievers' community, ${ }^{25}$ 'afiye 'health', ${ }^{26}$ sedk 'truth', ${ }^{27}$ gawáb 'answer', ${ }^{28}$ híall 'tricks', ${ }^{29}$ 'ákil' 'clever, intelligent', ${ }^{30}$ l'ázem 'it's necessary', ${ }^{31}$ kúl'l'e 'each, every', ${ }^{32}$ éshur 'months', šábri 'two months', ${ }^{33}$ márra 'time (vicis)', ${ }^{44}$ 'al'áma 'sign, mark', ${ }^{35}$ șáheb (pl. așháb) 'companion, friend; owner', ${ }^{36} a b l$ ' 'people, tribe', ${ }^{37}$ wa-stád dam 'and he considered (it) tremendous', wa-stánkar 'and he disapproved (it)', a'dár 'excuses', imtị̣án 'test, trial'.

In a few other cases, however, the Soqotri equivalents are fairly well attested throughout our texts, so it is hard to say why the compiler did not opt

25. Arabic words for 'priest' (or any other member of the Christian clergy) are of course unknown to the compiler, whereas 'imam' must have been avoided as too strongly bound to Islam. The choice of mas'ull is likely motivated by the Socialist background of Soqotra as part of PDRY where this word (literally, 'endowed with responsibility') was used as a calque of Russian ответственныцй (работник). The native word for 'chief, leader' is, undoubtedly, ribhen, note in particular ribhen di-'Etíhi 'head of the assembly' in Bittner 110. This lexeme (in all probability, an early borrowing from Arabic rabbān-) is so far unattested in our texts and may be out of use in today's language.

26. The native equivalents appear to be láfi (LS 235, properly 'strength, vitality') and torf (LS 446, properly 'healing; recovery').

27. The native equivalent is imben (LS 64), continuing the old Semitic root *'mn.

28. The native equivalent seems to be kili (LS 218).

29. Common in the Vienna corpus (LS 172), no native equivalent known to us.

30. The native equivalent is di-do'o 'that of knowledge' (LS 53).

31. This widespread Arabism is never used in the Vienna corpus, where the respective semantic slot is occupied by tálle, of unknown origin (LS 206). Until recently, only l'ázem was registered in our materials (CSOL I 606, II 530), and I was inclined to believe that tálle died out completely from the speech of our community, but last year it did crop up in a (still unpublished) text from the forthcoming CSOL III.

32. The genuine Soqotri word is kal, fully regular in the Vienna corpus (LS 219), but almost totally ousted by kúl'l'e in the speech of our community (see CSOL II 498 for one lone exception).

33. The genuine Soqotri word for month is ŝ́śbr (LS 426, Nakano 1986: 143). It is known to our consultants, but its relatively broad presence in CSOL I-II is almost certainly due to puristic replacements: in their spontaneous speech, the genetically related Arabic $\check{s} a b r$ is ubiquitous (see CSOL I 659, CSOL II 592).

34. Sporadically already in the Vienna corpus (LS 251) where, however, the normal exponent of this meaning is the autochthonous 'áblet, of uncertain etymology (LS 293-94).

35. Already in the Vienna corpus (LS 311). The native terms appears to be 'alm, attested in one of the unpublished texts from the forthcoming CSOL III.

36. This Arabic word, still missing from Müller's texts, has become exceedingly popular in today's Soqotri, in all of its multiple applications. In our text, it is once attested about Jonah as the 'owner' or 'occupant' of 'a movable grave' (a periphrasis for the whale), in which case di'ybe sábeb could have been easily replaced by the native Soqotri $b a \breve{s}$. In the other example, the plural așháb refers to Moses' 'companions' or 'compatriots' (the Israelites), and it is hard to say which autochthonous equivalent could be used in such a case - perhaps mábref 'friend' (in the speech of our community mostly used about romantic relations).

37. In the Vienna corpus, fábed (LS 335) and nábar (LS 265) are actively used for 'people, tribe', but both terms seem to be deeply obsolete in today's language. 
for them in agreement with his puristic program: kásșsa 'story', ${ }^{38}$ mórkeb (pl. marákeb) 'ship', ${ }^{39}$ bumár 'donkey'. 40

\section{- Borrowed discourse markers}

This volume offers valuable insights on the important role discourse markers have in transitional texts (Gintsburg 2020; Murray 2020; Liebhaber). I, however, limit myself to just listing discourse markers that are Arabic borrowings. As early as in the Vienna corpus, Soqotri narratives make ample use of Arabic discourse markers and other function words. The present text is no exception, see émme 'as for' (CSOL II 389), énne 'that' (LS 66, CSOL I 474, CSOL II 390), l'i'énne 'because' (CSOL I 474), 'asć 'perhaps' (LS 317, CSOL I 499, CSOL II 416), kál'l'ama 'when' (CSOL I 576, CSOL II 500).

\section{RELIGIOUS TERMINOLOGY: ARABIC LOANWORDS}

A great deal of Islamic religious terminology featuring in the text is directly borrowed from Arabic. As we have seen above, many abstract concepts have no proper exponents in the native Soqotri vocabulary, and this is all the more so for religious ideas pertaining to the Islamic creed. Here belong musl'imin 'Muslims', kuffár 'unbelievers', ${ }^{41}$ gánna or gínna 'Paradise', ${ }^{42}$ nabíy (pl. anbiyâ) 'prophet', ${ }^{43}$ mal'áyika 'angels', ${ }^{44}$ mețál'i' 'scrolls, sacred texts', ${ }^{45}$ áya (pl. ayát)

38. This Arabism, attested already in the Vienna corpus (LS 383), seems to be the commonest term for 'story, tale' in today's language, often featuring in CSOL I-II. Our narrators usually prefer the native (perhaps puristic) equivalent toutćyo, a verbal noun of $\dot{t} t i$ 'to tell' (CSOL I 480, II 396).

39. Well attested both in the Vienna corpus (LS 400) and in our texts (CSOL I 635, II 565). The native word șadák (LS 346) is, however, very well known and in common use up to this day (CSOL I 649, II 581).

40. There are at least two native terms for 'donkey' in Soqotri, viz. šánkahal (CSOL I 660) and šemálb̨n (LS 418). Both are well known to our consultants and seem to be in common use in their speech. Still, the Arabic loanword bumár (not yet attested in the Vienna corpus) is indeed growing in popularity (CSOL I 559, II 479, Wranik 505).

41. Already in the Vienna corpus (LS 223).

42. For the latter, clearly local form of this term, already attested in the Vienna corpus, v. LS 112.

43. Already in the Vienna corpus (LS 255).

44. Already in the Vienna corpus (LS 244).

45. Together with the four elements of their traditional Islamic nomenclature, viz. at-tawrát 'Pentateuch', az-zaburr 'Psalter', al'-'inğil' 'Gospels' and al'-kur'án 'Quran'. The word metál'i' as such does not seem to be attested in Arabic in any comparable meaning and must be a kind of local adaptation of muțāla 'a 'reading, study'. Similar 'pseudo-Arabic' lexical formations are not uncommon on Soqotra and would be worth of a special study of their own. 
'sign, revelation', aṣ-șal'awát 'daily prayers', ${ }^{46}$ yásgedu 'they prostrate', ${ }^{47}$ másgid 'Mosque', ${ }^{48}$ ḅásana (pl. hasanát) 'pious deeds', sayyi'át 'evil deeds', raḅim 'Merciful', arzák 'means of sustenance granted by God', ${ }^{49}$ 'ákab 'he punished', ${ }^{50}$ mu'gizát 'miracles'. Not unexpectedly, many of these terms were well known to the speakers of Soqotri as early as 120 years ago (see the references to individual lexemes in Leslau's Lexique adduced in the footnotes above).

\section{RELIGIOUS TERMINOLOGY: INHERITED VOCABULARY}

Of prime importance for our inquiry is to see where and how the compiler uses the native resources of his language while writing on a modern, nontraditional, rather sophisticated and, above all, religion-bound subject. What follows is a list of non-borrowed lexemes with religious connotations used in the text under scrutiny, with some annotations on their origin and previously known attestations. ${ }^{51}$

- kanínhin 'Lord, God' (LS 378, CSOL I 590, II 515). This word, also used as the title of the whole composition, is by far the most impressive element of the traditional religious vocabulary amalgamated with the Islamic creed, most prominently in the widely used double designation kanínbin álla.$^{52}$ As reported

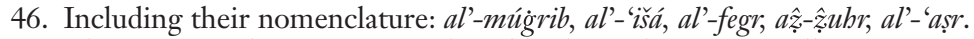

47. The corresponding segment of the Biblical Joseph story in Müller 1907: 47 features the native Soqotri verb égnen 'they bowed down'. However, already there it was probably felt to be inadequate to describe a true prostration, so that the non-assimilated Arabism ságdo was added in brackets.

48. Already in the Vienna corpus (LS 281).

49. Already in the Vienna corpus (LS 196).

50. The native Soqotri verb for 'to punish' is 'ódib (LS 298), an assimilated borrowing from Arabic 'addaba. In the Vienna corpus, it is well attested referring to divine punishment in Biblical translations (notably, Bittner 70), but in our texts its usual meaning is 'to pester, to annoy' rather than 'to punish' strictly speaking (CSOL I 485). Arabic 'āqaba is common when referring to divine punishment in the Quran (Ambros 2004: 192) and must have seemed, therefore, a suitable candidate to fill this semantic slot.

51. I will use this opportunity to mention a few New Testament religious terms coined by Müller and his informant for their translation of Mark. 'Sins': minheréten (Bittner 8), side by side with the Arabism hátoy (Bittner 40) < nóhor 'to transgress'; 'devil': di-kâšen (Bittner 14), literally 'thief, brigand'; 'demon': dídhe (Bittner 28), a very well known word up to this day, but carefully tabooed at least in external communication; 'faith': šeknnóo (Bittner 122) < šékna ' to be convinced', side by side with the Arabism imán (Bittner 40); 'the teachers of the law': il-kteb/il-yekóteb (Bittner 40, 48), literally 'those who wrote/write'; 'Pharisees': mešezheyéten (Bittner 48), literally 'the separated ones' $<\check{s} \varepsilon^{\prime} \varepsilon z i$ (in agreement with the semantic structure of the Hebrew/Aramaic background term).

52. A tenacious adherence to the native (non-Arabic) names of God is a hallmark of the Modern South Arabian speakers, which sharply distinguishes their languages from many other areas of the Muslim world where the old divine designations have been completely replaced by Allah. In the continental languages, such terms go back either to Proto-Semitic *'il- (Mehri ' $a l$, 
by our consultants, recent decades have witnessed a considerable deal of resentment against the use of this word in Islamic contexts: according to hardcore adherents of the rigid peninsular Islam, since kaninhin does not feature among the canonically established (Arabic) Divine Names, its application to God amounts to širk (polytheism). In more recent years, however, this zealous attitude seems to have relaxed and kaninhin is usually accepted as a legitimate native equivalent of Arabic 'ar-rabb 'the Lord'..$^{53}$ Etymologically, kaninhin appears to be derived from Proto-Semitic *kny 'to own, to possess' and must have thus originally meant 'master, lord'..$^{54}$

- Soqotri possesses a deeply rooted native verb for the prominent concept in religious vocabulary 'to create', viz. şók kab (LS 357), consistently applied to the Divine Creation in the Vienna corpus (Müller 1905: 1/1 and elsewhere). The compiler of our text regularly uses şókab with this meaning (Segments 35, 36, 37, 54, 56, 59, 100, 111), and only in two cases (Segments 98, 99) could he not resist the Arabizing pressure, replacing it with the corresponding Arabic verb bal'ák. The Soqotri verb has no good external etymology, but its other usages within Soqotri are quite telling as to its probable original meaning: as shown in CSOL II 584, it describes, inter alia, the formation of clumps of fresh butter in a shaking leather vessel..$^{55}$

- Soqotri 'ed 'soul, spirit of life' is the normal equivalent of both nafsand rüb- in Arabic, and is in common use both in the early texts ${ }^{56}$ and in today's language, as reflected in our materials (LS 298, CSOL I 485, CSOL II 401).

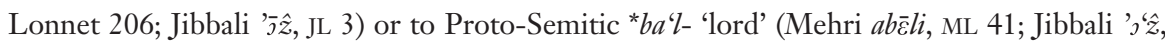

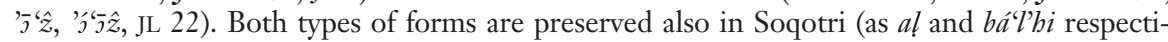
vely), but seem to be deeply obsolete and very rarely used (for the former, see CSOL II 99).

53. Interestingly enough, Müller's informant did not use kaninhin in his Biblical translations: when speaking about 'the Lord', he employs nínbin álla (Müller 1905: 3/7) or just ninbin (Bittner 110), the Soqotri word for 'elder brother', formerly also used when addressing the Sultan ('Majesty'). The etymological connection between ninhin and kaninhin - if any - remains uncertain, but certainly not impossible. If the latter incorporates a shortened form of káka 'brother' (which is also not to be ruled out), the derivation from *kny is, of course, to be abandoned.

54. See the well-known Biblical Hebrew expression kīnne šămayim wā-'āräș 'Owner of Heaven and Earth'.

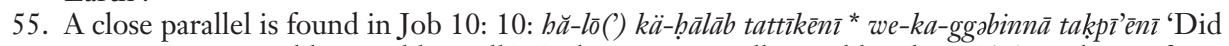
you not pour me like out like milk? Did you not curdle me like cheese?' (translation from Clines 215, with commentary 248). See also the probable connection between mворить 'to create' and mворог 'cottage cheese' in Russian and other Slavic languages (Vasmer IV 32, 34).

56. Often in religious contexts, see 'ed di-'álla 'the Spirit of God' in Müller 1905: 1/5 (Genesis creation narrative). Throughout Müller's Biblical translations, it alternates with another native lexeme fons. 
- Quite remarkable is the use of siyyat 'fire' about the Islamic Gehenna, a direct equivalent of Arabic an-nāru.

- As in the Vienna corpus (LS 320) and elsewhere in our texts (CSOL II 404), the verb 'éfer is used about divine pardon. Like several other terms in the present group, this verb is an early, naturalized borrowing from Arabic $\dot{g} f r .{ }^{57}$

- The Soqotri verb sáli 'to pray' is regularly used about Muslim prayer throughout the text. This is, again, an early adaptation of Arabic șallā, ubiquitous throughout the published Soqotri texts (LS 352, CSOL I 651, CSOL II 584).

- The verb šémen 'to believe', well attested in secular contexts elsewhere in the Soqotri texts (LS 64, CSOL I 474, CSOL II 390), is used here with the religious meaning 'to believe in God'. Note that, because of its morphological shape (causative-reflexive stem in š-), šémen cannot be borrowed from Arabic 'àmana, but must be an independent offshoot of the same proto-West Semitic root ${ }^{*} m n$.

- The verb katénab 'to return' is used with the prominent Islamic meaning 'to repent' (= 'to return to God'), undoubtedly a calque of Arabic ră̆a' $a$, amply documented with this meaning from the Quran onwards and continuing an old Semitic semantic pattern. ${ }^{58}$

- In the last segment of the text, describing the transformation of the unbelievers' prayer hall into a mosque, the building is designated káar di-'etíbi, literally 'house of assembly' - quite an appropriate term for a church ('єкК $\left.\lambda \eta \sigma^{\prime} \alpha\right){ }^{59}$

Of notice are a few mixed (Arabic-Soqotri) formations, such as 'ařs dikaninhin 'the Lord's throne' or šm di-sabt 'the day of Shabbat'. Such fixed nominal phrases could well have been borrowed from Arabic in their entirety ( ${ }^{*}$ aršu llähi and *yawmu s-sabti respectively), so the introduction of the Soqotri elements into them can only be explained by a conscious wish of the compiler. The same is true of tegadáhnen taw' an aw kurban 'come obediently or by

57. In the Arabic speech of our consulants, $\dot{g} f r$ is strictly reserved to divine pardon and is never used about human actors.

58. 'To return to God (humans)' = 'to repent'; 'to return to humans (God)' = 'to show favor, to forgive', both ubiquitous in Akkadian, Hebrew and Aramaic. For both usages, precedents are found in previously published Soqotri texts (Bittner 80, Muller 1905: 27, CSOL I 579).

59. Or, for that matter, a synagogue (bèt kənäsät). In the Soqotri version of the Gospel of Mark, $\varepsilon t i h i$ is repeatedly used about all kinds of religious gatherings (Bittner 24 and elsewhere). 
force' and gedáben ta'i in 'we've come obediently' in the Soqotri periphrasis of Quran 41: 11 (see below, Section 7). ${ }^{60}$

\section{OTHER PURISTIC FEATURES}

\section{- Old numerals}

In spite of its extreme conservatism, Soqotri was quick to abandon the inherited numerals from 'three' onwards, which, in today's speech, are restricted to some very traditional Bedouin contexts, such as counting livestock (Kogan/Bulakh 294). Instead, Arabic numerals are used throughout. ${ }^{61}$

From the very beginning of our joint activity in the framework of the CSOL project, our Soqotri friends must have seen the autochthonous numerals as a flagship issue in their puristic literary ambition, not only using them systematically in the texts that they themselves narrated, but also inserting them to replace the Arabic numerals in the texts obtained from other narrators. In the present composition, where numerals in general play quite a prominent role, any shade of Arabisms in this lexical segment has also been thoroughly avoided.

\section{- Personal names}

Throughout the text, the compiler opts for non-classical shapes of the names of the protagonists of the Islamic Sacred History, such as fir'un 'Pharaoh', ${ }^{62}$ móse 'Moses', yósef 'Joseph'63 and yónes 'Jonah'. Note also ya'kúb ber isḥák 'Jacob, son of Isaak', with the genuine Soqotri filiation marker $b \varepsilon r$ instead of Arabic $i b n$. When asked about the motivation behind his unorthodox choice, Isa Gum'an firmly replied: that's how we pronounce them here.

60. Admittedly, the opposite trend is also in evidence: in the creation account, the narrator introduces the Arabic terms for 'heaven' and 'earth' (kaninhin șókab as-samawát wa-l'-'arî̀ samawát ybóbi' wa-'aradún ybóbi' 'The Lord created the Heavens and the Earth: Seven Heavens and Seven Earths') even if the native equivalents íitin and bóybi are used elsewhere. It stands to reason that the choice of the Arabisms was motivated by the inability of Soqotri to produce plurals for the respective lexemes.

61. Surprisingly different from the continental MSA, where the native numerals are fully preserved in the colloquial speech.

62. Contrast the normal Arabic form fir'awn in Müller 1907: 51.

63. Müller's translation of the Biblical Joseph story (1907: 45-51) displays yúsef, the colloquial form ubiquitous in the Arabic dialects (as opposed to the Classical yüsuf). 


\section{Translating the Untranslatable}

In his account of the Islamic Sacred History, Isa was inevitably tempted to render some of the pertinent Quranic passages in a more or less literal manner, thus unconsciously achieving a number of purest samples of a Soqotri translation of the Holy Book. To investigate his translation technique - a most interesting task in itself - would be far beyond the aim and scope of the present contribution. Instead, I will limit myself to a brief tabular presentation of the relevant text segments and their Quranic sources.

sókkab ybóbi' samawát t’har |balaga sab'a samāwātin tibāgan. tahedédsen. (59) $(67: 3,71: 15)$

to'óge di'E be-mórkah óoben wa-šérkah mes 'âser wa-tri 'eybónten ir-rího. (86-87)

to'óge be-dî̀ mórkah di-rénhem wa-se tóod wa-tebấzior. (75-78)

drib bi-‘ạāka l-ḅăgara fa-nfağara minbu tnatā 'ašrata 'aynan. (2: 60)

'i drib bi-'așāka l-bahra fa-nfalaqa. (26: 63)

"ômor yósef e-di'ybe bébe bo sinik šsm wa-e'ere yésgedu

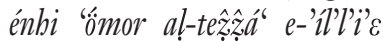
kakáybon. (88)

bo simik tok ábzezk 'ômor $\varepsilon$ bébe tó'o l'a'mér kanínbin ta'ámer. (104-05)

\begin{tabular}{|c|c|}
\hline$(104-05)$ & 102) \\
\hline $\begin{array}{l}\text { wa-ses țey šmm di-rey wa-šéken } \\
\text { tey šm di-rcy. (117) }\end{array}$ & $\begin{array}{l}\text { lahā širbun wa-lakum širbu } \\
\text { yawmin ma'lüm. (26: 155) }\end{array}$ \\
\hline $\begin{array}{l}\text { di-gédaḅ be-tey hásana yóusal } \\
\text { hey 'âser ḅasanát. (83) }\end{array}$ & 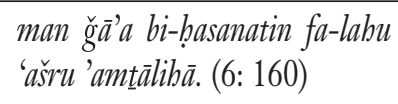 \\
\hline $\begin{array}{l}\text { kanínbin yeșál menál l'a'gób. } \\
\text { (83) }\end{array}$ & $\begin{array}{l}\text { wa-llähu yarzuqu man yašă’’u. } \\
(24: 38)\end{array}$ \\
\hline $\begin{array}{l}\text { "ömor tegadáḅnen taww'an aw } \\
\text { kurban 'ớmor gedábnen ța'icin. } \\
\text { (91) }\end{array}$ & $\begin{array}{l}\text { fa-qūla labā 'tiyā taww'an 'aww } \\
\text { karban qūlatā 'ataynā țāìinna. } \\
\text { (41: 11) }\end{array}$ \\
\hline
\end{tabular}

qūla yūsufu li-'abībi yā 'abati 'inñ ra'aytu š-šamsa wa-lqamara le sāŏidūn qāla lā taqsus 'alā 'ibwatika. (12: 4-5)

'inñ̄ 'arā 'annī 'adbabuka qāla yā 'abati f'al mā tu'maru. (37: 102)

labā sirbun wa-lakum sirbu It shall have one day for drinking, and you shall have one day' The one who performs one good deed, ten more will be bestowed upon him' 'The Lord gives to whom he wishes' 'He said: "Come obediently or by force". They answered him and said: "We have come obediently". 


\section{ANOTHER SAMPLE}

During the 2017 fieldwork season, I was busy gathering the text corpus of the forthcoming CSOL III. As usual, our language consultants offered us a wealth of specimens representing various genres of Soqotri oral literature. One piece, composed and written down by Isa Gum'an, particularly attracted my attention: while superficially resembling a fairy tale, it quickly proved to be another, somewhat disguised, sample of Islamic apologetics. What follows is a preliminary publication of this text, in Semitological transcription and English translation.

\begin{tabular}{|c|c|c|}
\hline 1. & $\begin{array}{l}\text { tad 'ag šódim šódim énne țrréday ásad } \\
\text { bə-șaḅrá }\end{array}$ & $\begin{array}{l}\text { One man had a dream. He had a dream: a lion was } \\
\text { pursuing him in a desert. }\end{array}$ \\
\hline 2. & tôo éraḅ ‘amk di-hádab késa sóbbor & Midway along, he came across a well. \\
\hline 3. & 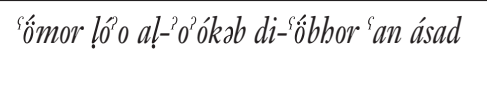 & $\begin{array}{l}\text { He said: 'Why don't I go down the well to save } \\
\text { myself from the lion?'. }\end{array}$ \\
\hline 4. & $\begin{array}{l}\text { ékob aybćray ásad 'af ya'ârah la-føg } \\
\text { di-šóbhor al-gésor l'ițćb idáy }\end{array}$ & $\begin{array}{l}\text { He went into the well. The lion followed him un- } \\
\text { til it reached the rim of the well. But it could not } \\
\text { get inside. }\end{array}$ \\
\hline 5. & 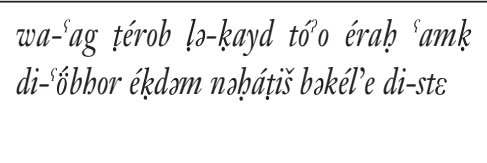 & $\begin{array}{l}\text { As for the man, he went down on a rope. When } \\
\text { he reached the middle of the well, he saw beneath } \\
\text { him a devouring snake. }\end{array}$ \\
\hline 6. & 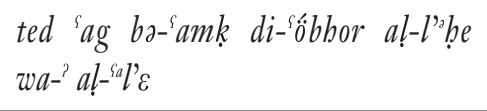 & $\begin{array}{l}\text { The man had to stop midway along - he could not } \\
\text { go up or down. }\end{array}$ \\
\hline 7. & 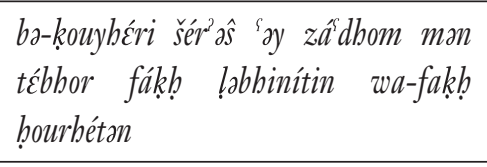 & $\begin{array}{l}\text { In a few seconds, some mice appeared in front of } \\
\text { him from the walls of the well - some of them } \\
\text { white, and some of them black. }\end{array}$ \\
\hline 8. & $\begin{array}{l}\text { wa-ébrah la-kayd wa-kaskésan díson } \\
\text { kayd }\end{array}$ & $\begin{array}{l}\text { And they leaped to the rope and began to gnaw } \\
\text { it. }\end{array}$ \\
\hline 9. & $\begin{array}{l}\text { wa-sag la bə-kayd wa-yástzt míta } \\
\text { yəbấẑ́ok }\end{array}$ & $\begin{array}{l}\text { And the man was holding the rope and waiting - } \\
\text { when would it cut. }\end{array}$ \\
\hline 10. & ál'l'e wa-asél di-š́rkạh man tébhor & But suddenly honey began to drip out of the walls. \\
\hline 11. & 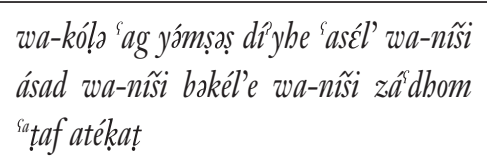 & $\begin{array}{l}\text { And the man began to suck the honey and forget } \\
\text { about the lion, and about the snake, and about the } \\
\text { mice, until he woke up. }\end{array}$ \\
\hline
\end{tabular}




\begin{tabular}{|c|c|c|}
\hline 7 & wa-ḅéra ag l'iftéker inćm dén a & $\begin{array}{l}\text { Now the man tried to figure out what it could } \\
\text { mean. }\end{array}$ \\
\hline & $\begin{array}{l}\text { wa-táber di’ál nébbi sómor byy šódimk } \\
\text { ța wa-ța }\end{array}$ & $\begin{array}{l}\text { And he went to a wise man and said to him: 'I } \\
\text { have had such and such a dream'. }\end{array}$ \\
\hline & $\begin{array}{l}\text { sómor ásad da di-yațáradk ybe mi } \\
\text { di-tónyhork }\end{array}$ & $\begin{array}{l}\text { He said: 'The lion that follows you, he is the } \\
\text { death that pursues you'. }\end{array}$ \\
\hline & 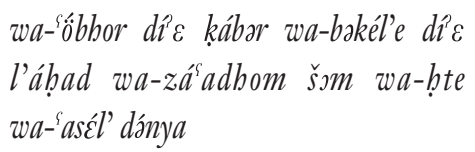 & $\begin{array}{l}\text { 'The well is your grave, and the snake is its lid, } \\
\text { and the mice are day and night, and the honey is } \\
\text { the pleasures of this world'. }\end{array}$ \\
\hline
\end{tabular}

It is easy to notice that the concept underlying this text (entitled 'The Grave' by its author) is germane to the one that must have guided Isa when he was compiling 'The Lord'. In fact, 'The Grave' is nothing but an extended allegoric narrative (a lengthy riddle, if one wishes) whose solution is revealed to the reader in the last two sections of the text. Its religious and moralistic purpose scarcely requires comment. The background of the story is unknown to me. Its plot might betray an Arabic origin ${ }^{64}$, but this is not necessary so, and deliberate stylization is not to be ruled out.

\section{Conclusion}

As I tried to show above, the concept of 'transitional text', fruitfully applied to poetry in modern literary research, can also be used about prose, and not necessarily narrative. The specificity of the Soqotri case, as reflected in two texts composed by Isa Gum'an, takes its roots in the author's strong religious motivation. It remains to be studied to what extent this path has been (or is being) followed by other emerging literatures of the Islamic world.

As a minority language, Soqotri finds itself under continuous pressure from written and spoken Arabic, whose prestige is particularly high in the religious sphere. Isa Gum'an's brave and masterful attempt to counter this trend has yielded a peculiar amalgamation of Islamic modernity and traditional, at times patently archaic, resources and techniques carefully elaborated by generations of his illiterate forefathers.

64 'The Grave' features a few transparent Arabisms (ásad 'lion', șabrá 'desert', l'áhad 'lid of the grave', dánya 'this world'), but otherwise is a pure and genuine specimen of the Soqotri narrative art. 
While essentially linguistic in its scope, my study will hopefully attract the interest of specialists from neighbouring disciplines, better prepared for a comprehensive assessment of the nascent written and printed prose of Soqotra.

\section{REFERENCES}

ad-Da'rhi, Isa Gum'an, Leonid Kogan and Dmitry Cherkashin. "The Lord: An Apology for the Muslim Faith from the Island of Soqotra". Fournal of Semitic Studies 64 (2019): 535-63.

Ambros, Arne. A Concise Dictionary of Koranic Arabic. Wiesbaden: Reichert, 2004.

Bittner, Maximilian. Vorstudien zur Grammatik und zum Wörterbuch der Soqotri-Sprache, III: Eine Soqotri-Version der ersten sechs Kapitel aus dem Marcus-Evangelium. Wien: Hölder, 1918.

Chyet, Michael. "A Thing the Size of Your Palm. A Preliminary Study of Arabic Riddle Structure”. Arabica 35 (1988): 267-92.

Clines, David. Fob 1-20. Dallas: World Books, 1989.

Elie, Serge. A Post-Exotic Anthropology of Soqotra. 2 vols. Cham: Palmgrave Macmillan, 2020.

Ford, John C. "Two or III Feet Apart: Oral Recitation, Roman Numerals, and Metrical Regularity in Capystranus". Neophilologus 102.4 (2018): 573-93. Gintsburg, Sarali. "It's got some meaning but I am not sure ... The role of the particle (wa)-ma in the oral and transitional poetry of the Jbala (northern Morocco from the cognitive perspective". Pragmatics \& Cognition 24.3 (2017): 474-95.

Gintsburg, Sarali. Formulaicity in fbala Poetry. Tilburg: Prisma, 2014.

Gintsburg, Sarali. "Lost in dictation. A cognitive approach to oral poetry: Frames, scripts and 'unnecessary' words in the Jebli ayyu". Language \& Communication 64 (2019): 104-15.

Gintsburg, Sarali. "Living Through Transition: The poetic tradition of the Jbala between literacy and orality at a time of major cultural transformations". Transitional Texts: Drifting between the Oral and the Written. Eds. S. Gintsburg, J. Ford \& A. Barandiaran. Special issue of Rilce 36.4 (2020): 1434-54.

Jahner, Elaine. "Transitional Narratives and Cultural Continuity”. Boundary 2 19 (1992): 148-79.

Jeffery, Arthur. A Reader on Islam: Passages from Standard Arabic Writings Illustrative of the Beliefs and Practices of Muslims. 'S-Gravenhage: Mouton, 1962. 
Johnstone, Thomas. Fibbäli Lexicon. Oxford: Oxford UP, 1981 (= JL).

Johnstone, Thomas. Mebri Lexicon. London: SOAS, 1987 (= ML).

Kogan, Leonid, and Maria Bulakh. "Soqotri". The Semitic Languages. Eds. John Huehnergard and Na'ama Pat-El. 2nd ed. London: Routledge, 2019. 280-320.

Leslau, Wolf. Lexique Soqotri (Sudarabique moderne) avec comparaisons et explications étymologiques. Paris: Klincksieck, 1938.

Liebhaber, Samuel. "Messages, Texts, and Rhetorical Detachment in Contemporary Mahri Poetry". Transitional Texts: Drifting between the Oral and the Written. Eds. S. Gintsburg, J. Ford \& A. Barandiaran. Special issue of Rilce 36.4 (2020): 1403-14.

Lonnet, Antoine. "Emprunts intra-sémitiques: l'exemple des emprunts arabes en sudarabique moderne”. Aula Orientalis 23 (2005): 199-206.

Moscoso García, Francisco. "La haquitía a partir de la obra El mazal de los pobres de Elie Benchetrit". Transitional Texts: Drifting between the Oral and the Written. Eds. S. Gintsburg, J. Ford \& A. Barandiaran. Special issue of Rilce 36.4 (2020): 1373-402.

Müller, David. Die Mehri- und Soqotri-Sprache, I: Texte. Wien: Hölder, 1902.

Müller, David. Die Mehri- und Soqotri-Sprache, II: Soqotri-Texte. Wien: Hölder, 1905.

Müller, David. Die Mebri- und Soqotri-Sprache, III: Šbauri-Texte. Wien: Hölder, 1907.

Murray, Alan V. "Formulaic Language in the Livonian Rhymed Chronicle: Set Phrases and Discourse Markers in Middle High German History Writing". Amsterdamer Beiträge zur älteren Germanistik 79.1 (2019): 86-105.

Murray, Alan V. "The Livonian Rhymed Chronicle as a Transitional Text: Formulaic Language in a Middle High German Verse Chronicle". Transitional Texts: Drifting between the Oral and the Written. Eds. S. Gintsburg, J. Ford \& A. Barandiaran. Special issue of Rilce 36.4 (2020): 1324-43.

Nakano, Akio. Comparative Vocabulary of Southern Arabic. Tokyo: ISLAA, 1986.

Naumkin, Vitaly, Leonid Kogan et al. Corpus of Soqotri Oral Literature. Vol. 1. Leiden: Brill, 2014 (= CSOL I).

Naumkin, Vitaly, Leonid Kogan et al. Corpus of Soqotri Oral Literature. Vol. 2. Leiden: Brill, 2018 (= CSOL II).

Vasmer, Max. Etimologicheskiy slovar' russkogo yazyka. Moscow: Nauka, 1989.

Wranik, Wolfgang. Fauna of the Soqotra Archipelago: Field Guide. Rostock: Universität Rostock, 2003. 